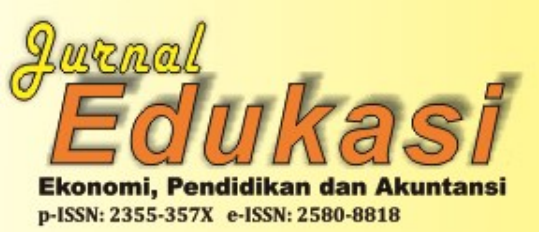

Program Studi Pendidikan Akuntansi

Fakultas Keguruan Dan Ilmu Pendidikan UNIVERSITAS GALUH CIAMIS Jl. R. E. Martadinata No. 150 Ciamis, 46274 Jawa Barat $+62265-776787$

https://jurnal.unigal.ac.id/index.php/edukasi/article/view/2837

\title{
ANALISIS HUBUNGAN ANTARA DIMENSI BUDAYA KINERJA ORGANISASI DENGAN KERANGKA TEORI HOFSTEDE
}

(Studi kasus pada Industri Travel Agent yang ada di Negara Indonesia dan Malaysia)

Oleh:

Wulansari Syaidatul Sahar', Asep Kurniawan ${ }^{2}$

Program Studi Akuntansi STIE Sutaatmadja, Indonesia

Email: wulansarisyaidatulsahar@gmail.com ${ }^{1}$, asep@,stiesa.ac.id ${ }^{2}$

Sejarah Artikel: Diterima September 2020, Disetujui Oktober 2020, Dipublikasikan November 2020

\begin{abstract}
ABSTRAK
Budaya organisasi yang efisien merupakan salah salah satu faktor yang selalu dikaitkan dengan kesuksesan organisasi. Dimana, kinerja organisasi ini berhubungan dengan cara kerja sekelompok orang yang terorganisasi dengan tujuan tertentu. Hofstede's Model diadopsi dalam penelitian ini karena kesederhanaannya dan kemampuannya untuk membimbing dalam pemahaman tentang budaya yang nantinya akan dihubungkan dengan pengaruh, baik sebagai individu atau sebagai kelompok, terhadap perilaku dan keputusan yang akan memengaruhi kinerja pada karyawan travel. Penelitian ini bertujuan untuk mengetahui hubungan antara dimensi budaya kinerja organisasi dengan kerangka teori hofstede. Data yang diperoleh dari hasil wawancara, observasi dan dokumentasi kemudian dianalisis secara mendalam. Sampel yang digunakan adalah karyawan travel Malaysia dan Indonesia dengan menggunakan teknik cluster sampling. Hasil penelitian menunjukkan hasil dimensi power distance rendah, dimensi group attachment dalam collectivisme, dimensi gender association lebih di dominasi oleh sisi feminity, dimensi high uncertainty avoidance, dimensi time orientation menunjukkan long term orientation, dan indulgence.
\end{abstract}

Kata Kunci: Budaya Organisasi, Dimensi Budaya Hofstede.

\section{ABSTRACT}

An efficient organizational culture is one of the factors that is always associated with organizational success. The performance of this organization is related to the workings of a group of people organized with specific goals. Hofstede's Model was adopted in this study because of its simplicity and ability to guide the understanding of the culture, which will later be associated with the influence, either as an individual or group, on behavior and decisions that will affect the performance of travel employees. This study aims to determine the relationship between the cultural dimensions of organizational performance and Hofstede's theoretical framework. The data obtained from interviews, observation, and documentation were then analyzed in depth. The samples used were Malaysian and Indonesian travel employees using a cluster sampling technique. The results show that the dimensions of low power distance, the dimension of group attachment in collectivism, the gender association dimension are more dominated by the femininity side, the high uncertainty avoidance dimension, the time orientation dimension shows long term orientation and indulgence.

Keywords: Organizational Culture, Hofstede's dimension of culture

\section{PENDAHULUAN}

Kinerja organisasi sangat penting dalam konteks perkembangan yang efektif di suatu bangsa, yang berarti mencakup pencapaian dari suatu organisasi yang sebenarnya untuk memperoleh hasil yang maksimal. Budaya organisasi didasarkan pada kinerja organisasi. Budaya organisasi yang efisien dapat diakui sebagai salah salah satu faktor yang selalu dikaitkan dengan kesuksesan dari suatu 
organisasi. Dimana, kinerja organisasi ini berhubungan dengan cara kerja sekelompok orang yang terorganisasi dengan tujuan tertentu. Cara mengukur budaya yang digunakan oleh para peneliti ilmu sosial adalah dengan menggunakan dimensi-dimensi budaya yang dikembangkan oleh Hofstede. Hofstede's Model diadopsi dalam penelitian ini karena kesederhanaannya dan kemampuannya untuk membimbing dalam pemahaman tentang budaya yang nantinya akan dihubungkan dengan pengaruh, baik sebagai individu atau sebagai kelompok, terhadap perilaku dan keputusan yang akan memengaruhi kinerja pada karyawan travel. Penelitian ini bertujuan untuk mengetahui hubungan antara dimensi budaya kinerja organisasi dengan kerangka teori hofstede. Studi kasus digunakan sebagai pendekatan dimana data yang didapatkan sesuai dengan realita yang terjadi dilapangan. Data yang diperoleh dari hasil wawancara, observasi dan dokumentasi kemudian dianalisis secara mendalam. Sampel yang digunakan adalah karyawan travel Malaysia dan Indonesia dengan menggunakan teknik cluster sampling.

(Hofstede dan Minkov, 2010); mendefinisikan budaya sebagai "pemrograman kolektif dari pikiran yang membedakan anggota dari satu kelompok atau kategori orang dari yang lain". Cara mengukur budaya yang digunakan oleh para peneliti ilmu sosial adalah dengan menggunakan dimensi-dimensi budaya yang dikembangkan oleh Hofstede dimana dimensi-dimensi tersebut meliputi: Power Distance, Group Attachment, Gender Association, Uncertainty Avoidance, Time Orientation dan Indulgence. Penelitian ini mengadopsi Hofstede's Model karena kesederhanaannya dan kemampuannya untuk membimbing dalam pemahaman mengenai budaya yang nantinya akan dihubungkan dengan pengaruh, baik sebagai individu atau sebagai kelompok, terhadap perilaku dan keputusan yang akan memengaruhi kinerja karyawan travel.

Hofstede mengakui adanya variasi dalam perilaku di antara anggota budaya apapun. "Menurutnya, pola budaya hanya menunjukkan reaksi dan perilaku yang mungkin dan dapat dimengerti berdasarkan masa lalu seseorang tidak mungkin memiliki semua individu dari satu negara tertentu berperilaku persis sama" (Hofstede, 1991). Dengan kata lain, pengukuran serta pemahaman mengenai suatu budaya masih sangat relevan sampai sekarang meskipun pemikiran dan perilaku seseorang di setiap wilayah memiliki perbedaan. Budaya bukan hanya alat untuk mengatasi, tetapi juga dimaksudkan untuk menciptakan kesadaran atau pembelajaran. Ini menopang aktivitas manusia dan membantu menjelaskan banyak perilaku manusia. Sebagian besar studi tentang budaya bertujuan untuk menemukan persamaan dan perbedaan antara orang-orang dari lingkungan budaya yang sama atau sangat berbeda. Persamaan dan perbedaan dalam budaya dijelaskan dalam dua teori umum budaya yang melibatkan konsep konvergensi dan divergensi. Sejumlah besar studi yang dilakukan pada budaya didasarkan pada pemahaman bahwa budaya orang dari berbagai latar belakang etnis atau kelompok memiliki beberapa perbedaan.

"Perbedaan peran manajer terhadap operasional suatu industri yang memiliki perbedaan pada beberapa negara dapat menimbulkan paradoks tentang seberapa banyak pendekatan lokal yang harus diambil versus berapa banyak dari pengalaman global industri" (Jones 1999; Brotherton dan Adler, 1999; Jones dan McCleary, 2004).

Dalam konteks perkembangan yang efektif di suatu bangsa kinerja organisasi merupakan salah satu hal yang sangat penting, yang berarti mencakup pencapaian yang sebenarnya dari suatu organisasi untuk memperoleh hasil yang maksimal. Budaya organisasi ini dapat didasarkan pada kinerja organisasi. Salah satu faktor kesuksesan dari suatu organisasi erat kaitannya dengan budaya organisasi yang efisien. Dimana, pencapaian tujuan dari kinerja organisasi ini berkaitan dengan cara terorganisirnya kerja kelompok seseorang. untuk mencapai target daripada suatu organisasi, sebuah perusahaan menaruh harapan yang tinggi atas performa karyawannya baik atasan maupun bawahan. Jika kinerja karyawan rendah akan menjadi salahsatu alasan bagi kinerja organisasi yang buruk dan ketidak efisienan dalam organisasi.

Hofstede menganalisis budaya dari beberapa bangsa dan mengelompokkannya ke dalam beberapa dimensi. Dimensi budaya menurut (Hofstede, 2001);

"Dimension of culture is the comparison of cultures presupposes that there is something to be compared - that each culture is not so unique that any parallel 
with another culture is meaningless". Pengertian tersebut dapat dipahami bahwa untuk mengatahui perbandingan budaya dari suatu bangsa dapat dilakukan dengan cara membandingkan budaya satu bangsa dengan bangsa yang lainnya, dan sebenarnya setiap budaya dari suatu bangsa tidaklah begitu unik, dengan kata lain setiap budaya yang paralel dengan kebudayaan lain tidak memiliki makna yang begitu berarti.

Berikut ini adalah enam dimensi budaya yang dibangun oleh Hofstede:

a. Power Distance

Power distance atau jarak kekuasaan adalah sejauh mana anggota yang mempunyai posisi yang kurang kuat dalam perusahaan dapat menerima bahwasanya kekuasaan didistribusikan secara tidak merata. Dimana beberapa orang dianggap superior dibandingkan dengan yang lainnya berdasarkan tingkatan sosial, tingkatan pendidikan dan tingkatan jabatan atau faktor lainnya yang merupakan bentuk power distance yang tinggi. "Dimensi ini merefleksikan nilai dari anggota masyarakat yang kurang memiliki kekuasaan" (Hofstede, 2001). Power distance dibedakan menjadi dua yaitu power distance rendah dan power distance tinggi. Dalam masyarakat dengan power distance rendah akan tercerminkan dalam jarak emosional antara atasan dan bawahan yang relatif kecil, dimana bawahan dapat dengan mudah mendekati dan mendebat atasannya, di sisi lain power distance yang tinggi tidak memungkinkan bagi bawahan untuk mendekati dan mendebat atasannya karena jarak emosional antara keduanya trelatif tinggi.

\section{b. Group Attachment}

Dimensi ini berkaitan dengan sejauh mana individu terintergasi kedalam suatu kelompok, konsep group attachment terdiri dari individualisme dan kolektivisme, konsep individualisme merupakan orang-orang yang mencari dan melindungi kepentingan mereka sendiri atas tujuan bersama dari masyarakat dan peran mereka dalam masyarakat, sedangkan budaya kolektivisme orang-orang lebih cenderung berkelompok dan memiliki tujuan saling menjaga satu sama lain.

\section{c. Gender Association}

Berdasarkan konsep budaya gender association dibedakan dengan kata masculinity dan femenity yang juga ditentukan oleh pekerjaan, tingkat pendidikan, dan strata sosial.
Dalam masculinity sendiri lebih banyak membahas tentang preferensi dalam kehidupan sosial.

\section{d. Uncertainty Avoidance}

Menurut (Hofstede dan Minkov, 2010); "Uncertainty avoidance mengukur sejauh mana masyarakat merasa terancam terhadap situasi yang tidak pasti, tidak diketahui, ambigu, dan tidak terstruktur. Orang-orang yang memiliki dimensi budaya high uncertainty avoidance cenderung lebih emosional. "Masyarakat yang memiliki penghindaran ketidakpastian tinggi cenderung merasa terancam apabila menghadapi situasi yang tidak pasti, dan akan membentuk institusi untuk menghindari ketidakpastian ini" (Hofstede, 2001). Sedangkan low uncertainty avoidance menerima dan merasa nyaman dalam situasi yang tidak terstruktur atau lingkungan yang kerap kali mengalami perubahan.

\section{e. Time Orientation}

Hal ini terkait kepada pilihan dari fokus untuk usaha manusia dari waktu ke waktu muklai dari masa depan, saat ini, atau masa lalu. Time orientation terbagi menjadi orientasi jangka panjang dan orientasi jangka pendek dimana orientasi tersebut menggambarkan fokus dan nilai-nilai budaya yang menyangkut pola pikir masyarakat.

\section{f. Indulgence}

Indulgence merupakan dimensi Hofstede yang merefleksikan masyarakat yang dalam tatanan sosialnya sangat mentoleransi pengekspresian hasrat dan perasaan, terutama yang berkaitan dengan pemanfaatan waktu luang, mencari hiburan bersama teman pembelian barang, konsumsi, dan hal-hal yang berbau seksual. Ujung dari dimensi ini adalah restraint yang merefleksikan masyarakat yang menahan kesenangan-kesenanganyang disebutkan sebelumnya. "Masyarakat yang termasuk dalam kategori ini cenderung kurang menikmati hidup" (Hofstede et al, 2008).

Budaya dalam sebuah organisasi melibatkan sekumpulan pengalaman, filosofi, ekspektasi dan juga nilai yang terkandung didalamnya yang nantinya akan tercermin dalam perilaku anggota, mulai dari inner working, interaksi dengan lingkungan diluar organisasi sampai ekspektasi masa depan. Suatu budaya organisasi bersifat dinamis karena dapat diciptakan dan diperbaharui sejalan dengan interaksi anggota terhadap perkembangan organisasi. Struktur dan budaya merupakan sebuah siklus yang secara terus menerus saling 
melengkapi satu sama lain, dimana sebuah struktur organisasi disusun berdasarkan dari nilai yang terdapat dalam budaya organisasi sementara nilai yang terdapat dalam budaya organisasi lahir dari interaksi, komunikasi, dan kebiasaan yang sudah terjadi dalam struktur organisasi. Kinerja merupakan konsep yang digunakan oleh suatu organisasi untuk menilai seberapa besar hasil yang telah dicapai dan proses pelaksanaan pekerjaan untuk mencapai tujuan organisasi. Menurut Mangkunegara (2008) "Istilah kinerja berasal dari kata job performance atau actual performance yakni prestasi kerja atau prestasi yang ingin dicapai”.

Kinerja organisasi merupakan gambaran mengenai hasil kerja organisasi dalam mencapai tujuannya yang tentu saja akan dipengaruhi oleh sumber daya yang dimiliki oleh organisasi tersebut. Karyawan yang sudah memahami keseluruhan nilai organisasi akan menjadikan nilai-nilai tersebut sebagai suatu kepribadian organisasi yang di wujudkan menjadi perilaku keseharian mereka dalam bekerja, sehingga akan menjadi kinerja individual. Untuk mencapai tujuan dari organisasi pada bisnis ini berikut hal-hal yang harus diperhatikan:

a. Kepemimpinan

$$
\text { Menurut Moejiono }
$$

"Kepemimpinan adalah kemampuan dalam memberikan pengaruh satu arah, karena kepemimpinan mungkin memiliki beberapa kualitas tertentu yang membuatnya berbeda dengan pengikutnya". Kepemimpinan menjadi salah satu faktor penting bagi keberhasilan sebuah organisasi, untuk itu ada beberpa sikap kepemimpinan yang perlu diterapkan dalam berorgnisai, yaitu: menjalin kedekatan dengan anak buah, memberikan semangat dan motivasi, serta memberikan kepercayaan dan tanggung jawab.

\section{b. Ketanggapan}

Ketanggapan yaitu suatu kebijakan dalam membantu dan memberikan pelayanan yang cepat (responsive) dan tepat kepada pelanggan dengan penyampaian informasi yang jelas. Karena Membiarkan konsumen menunggu tanpa adanya suatu alasan yang jelas menyebabkan persepsi yang negatif pada pelayanan.

\section{c. Motivasi}

Motivasi adalah suatu keadaan yang mendorong seseorang untuk melakukan suatu kegiatan sehingga ia dapat mencapai tujuannya. Motivasi merupakan fungsi dari berbagai macam variabel yang saling mempengaruhi yang terjadi dalam diri manusia yang secara psikologis terjadi interaksi antara sikap, kebutuhan, persepsi, proses belajar dan penyelesaian persoalan.. Menurut Nimran (2005) "Motivasi adalah sebagian keadaan dimana usaha dan kemauan keras seseorang diarahkan pada pencapaian hasil-hasil tertentu". Motivasi terdiri dari dua jenis yaitu motivasi internal yang tumbuh dalam diri seseorang tanpa dipengaruhi oleh orang lain untuk melakukan sesuatu dalam mencapai tujuannya dan motivasi eksternal yang datang dari luar diri seseorang untuk mencapai tujuannya.

d. Keramahan

Menurut Heri Kuswara (2009) "Ramah adalah sikap santun terhadap semua orang agar orang lain merasakan kenyamanan dan perasaan senang saat bersama kita". Suatu organisasi akan berkembang tidak hanya dengan bersikap ramah saja tetapi empati yang ditunjukkan oleh karyawan ataupun atasan kepada konsumen juga sedikit banyaknya akan berdampak pada kepuasan dari konsumen atas pelayanan yang di berikan oleh suatu organisasi.

e. Kemampuan

Menurut

"Kemampuan atau kompetensi adalah karakteristik yang mendasari seseorang berkaitan dengan efektifitas kinerja individu dalam pekerjaannya atau karakteristik dasar individu yang memiliki hubungan kausal atau sebagai sebab akibat dengan kriteria yang dijadika acuan, efektif atau berkinerja prima atau superior ditempat kerja pada situasi tertentu". Kemampuan individu tersusun dari dua faktor yaitu: Kemampuan intelektual yang diperlukan untuk menjalankan kegiatan mental seperti kecerdasan, pemahaman verbal, kecepatan perceptual, penalaran induktif, penalaran deduktif, visualisasi dan ingatan. Dan, Kemampuan fisik yang diperlukan untuk melakukan tugas-tugas yang menuntut stamina, kecekatan, kekuatan dan keterampilan.

Berdasarkan hal tersebut diatas, peneliti tertarik untuk meneliti lebih jauh berkaitan dengan hubungan antara keduanya. Dengan judul "Analisis hubungan antara dimensi budaya kinerja organisasi dengan kerangka teori Hofstede".

\section{METODE PENELITIAN}

Metode penelitian teknik yang digunakan untuk meneliti suatu fenomena yang terjadi dilingkungan sekitar. Pada penelitian ini penulis menggunakan metode kualitatif dengan 
menggunakan deskriptif. Menurut Bogdan dan Taylor dalam Moleong (2007) "Penelitian kualitatif adalah sebuah prosedur penelitian yang manghasilkan data deskriptif yang terdiri dari kata-kata tertulis atau lisan, dari orangorang dan prilaku yang dilihat". Jenis penelitian yang digunakan dalam penelitian ini adalah penelitian kualitatif deskriptif.

Sumber data dalam penelitian ini berupa sumber data primer dan sekunder yang diperoleh dari narasumber sesuai dengan kebutuhan dari peneliti melalui tenik cluster sampling pada negara Indonesia dan Malaysia, kemudian data yang telah diperoleh dari hasil wawancara terstruktur, observasi dan dokumentasi dengan instrument penelitian karyawan travel agent negara Indonesia dan Malaysia dengan beberapa alat berupa pedoman wawancara, handphone, dan alat tulis yang kemudian dianalisis secara mendalam dengan menggunakan analisis deskriptif kualitatif..

Teknik analisis data deskriptif merupakan suatu cara dalam meneliti status sekelompok manusia, suatu objek, kondisi, sistem pemikiran, atau juga peristiwa masa sekarang. Jenis metode kualitatif ini berusaha menjelaskan fenomena sosial pada saat tertentu. Aktivitas dalam analisis data kualitatif dilakukan dengan berinteraksi secara langsung dan setiap tahapan penelitian saling berhubungan dan mempengaruhi satu sama lain..

\section{HASIL PENELITIAN DAN PEMBAHASAN}

Proses terbentuknya budaya organisasi tidak secara instan tercipta melainkan melalui berbagai tahapan dan proses yang panjang, dan ketika budaya organisasi sudah terbentuk secara otomatis hal ini akan mempengaruhi kriteria dalam pemilihan SDM yang baik, yang kemudian akan tercermin dalam pola pikir dan kinerja para karyawannya.

Berikut adalah data dari karyawan yang telah peneliti wawancarai selama di perjalanan KKL ke malaysia.

Tabel 1:

\begin{tabular}{|c|c|c|c|}
\hline \multicolumn{4}{|c|}{ Data Karyawan Travel } \\
\hline & Nama & Usia & Lama Bekerja \\
\hline \multirow{6}{*}{ 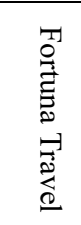 } & Ocky & 28 tahun & 6 tahun \\
\hline & Agil & 35 tahun & 1 tahun \\
\hline & Anri & 23 tahun & 2 tahun \\
\hline & Regi & 20 tahun & 1 tahun \\
\hline & Mela & 25 tahun & $<$ tahun \\
\hline & Indah & 20 tahun & 1 tahun \\
\hline \multirow{4}{*}{ 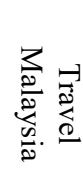 } & Nita & 50 tahun & $>15$ tahun \\
\hline & Fatin & 29 tahun & 5 tahun \\
\hline & Nor Syafiqah & 29 tahun & 3 tahun \\
\hline & Nana & 27 tahun & 8 tahun \\
\hline
\end{tabular}

Dan berikut hasil dari jawaban wawancara terstruktur dengan narasumber berkaitan dengan dimensi budaya berdasarkan kerangka teori Hofstede:

a. Dimensi Power Distence

Pada dimensi ini peneliti mengajukan tiga pertanyaan seperti:

"Seberapa penting peran seorang manager atau atasan di travel ini? Ketika Manager/atasan sedang merencanakan suatu pekerjaan apakah penting bagi anda untuk manager tersebut meminta saran dari anda?Apakah anda termasuk karyawan yang takut untuk secara terbuka tidak setuju dengan manajer /atasan anda dalam merencanakan suatu pekerjaan?"
Dari ketiga pertanyaan tersebut diperoleh jawaban yang hamper sama dimana untuk pertanyaan pertama semua karyawan maupun owner menjawab:

"peran manager itu sanget penting karena manager itu yang mengatur segala kegiatan operasional perusahaan mulai dari perencanaan, pengorganisasian, pengarahan, pengkoordinasi dan pengendali seluruh sumberdaya yang ada guna tercapainya tujuan perusahaan".

"Karena ini adalah bisnis travel maka pernting bagi seorang atasan untuk meminta saran kepada seluruh karyawan karena dalam pengambilan keputusan dari bisnis ini di ambil oleh atasan namun harus diketahui oleh seluruh karyawan guna 
menghindari terjadinya miss antar karyawannya"

Lalu jawaban dari pertanyaan ketiga seluruh karyawan di travel ini menjawab

"tidak pernah takut untuk mengutarakan pendapat mereka kepada manajer karena baik dan buruk harus dibicarakan tujuannya adalah untuk kebaikan bisnis travel itu sendiri”.

dari ketiga pertanyaan ketiga jawaban atas pertanyaan tersebut peneliti menyimpulkan bahwa power distance pada industri travel baik yang ada di negara Indonesia maupun Malaysia berada pada level power distance rendah karena meskipun tugas seorang manager adalah mengatur dan mengarahkan karyawannya agar kegiatan dapat berjalan dengan baik, akan tetapi pada lini bisnis travel ini meminta saran dari karyawan dan saling mengutarakan pendapat itu sangat diperlukan bahkan harus di lakukan karena hal ini akan mempengaruhi dalam pengambilan keputusan oleh manager untuk memberikan service yang terbaik kepada pengguna jasa travel mereka, dengan kata lain dikatakan power distance rendah karena walaupun peran manager itu penting, namun jarak emosional antara atasan dan bawahan relatif kecil.

\section{b. Dimensi Group Attachment}

Pada dimensi ini peneliti lebih menitikberatkan pertanyaan pada individualisme dari para karyawan travel dimana pertanyaan tersebut meliputi:

Apa yang membuat anda tertarik dengan pekerjaan anda saai ini? Berapa lama anda mendapatkan waktu istirahat saat bekerja? Apakah bagi anda waktunya cukup atau kurang? Dalam hidup anda, seberapa penting peran pendidikan untuk dapat dihormati dan dihargai oleh keluarga dan teman anda? Menurut anda, apakah pendidikan berpengaruh dalam mendapatkan pekerjaan yang stabil dan sesuai dengan harapan anda?

Jawaban yang di peroleh adalah karyawan "merasa menikmati pekerjaan ini karena pekerjaan ini merupakan hobi yang di bayar selain mereka dapat berkunjung ke tempat-tempat yang belum pernah mereka kunjungi ini juga merupakan tantangan bagi mereka karena bertemu dengan orang-orang baru dan tempat baru"

Menurut penulis selain hanya kesenangan semata dalam pekerjaan ini juga seseorang yang bekerja di travel agent bisa mendapatkan pengalaman yang berharga dan juga mendapatkan pengetahuan secara tidak langsung karena sudah pasti sebelum melakukan perjalanan bersama para traveler mereka di wajibkan untuk mengetahui sejarah atau informasi apapun mengenai tempat yang akan mereka kunjungi bersama para traveler dan informasi tersebut penting untuk di bagikan kepada para traveler agar traveler juga mendapatkan tambahan informasi mengenai tempat yang dikunjunginya, apalagi tantangan dari pekerjaan ini adalah bertemu dengan orang baru maka mereka juga harus bisa menyesuaikan diri mereka dengan orang-orang yang memiliki karakter yang tidak sama antara satu dan yang lainnya.

Meskipun pekerjaan mereka ini menyenangkan namun mereka menganggap bahwasanya "pendidikan juga sangatlah penting bukan hanya karena untuk dihormati oleh orang lain dengan pendidikan akan dapat menambah wawasan, penhgetahuan dan pengalaman baru juga agar dapat memiliki banyak relasi karena pekerjaan sebagai travel agent ini selain mengharuskan karyawan untuk memberikan pelayanan dan kepuasan kepada pelanggan karyawan juga harus menjalin relasi yang baik dengan para traveler. Selain itu ada beberapa hal yang tidak dapat di peroleh dengan pendidikan pertama pengetahuan dan yang kedua pengalaman, ketika pengalaman didorong oleh pengetahuan maka cara bersikap seseorang akan lebih tersusun dan lebih baik".

Untuk pertanyaan mengenai pengaruh pendidikan dalam mendapatkan pekerjaan yang stabil, hampir semua karyawan travel agent menjawab "pendidikan sangat berpengaruh apalagi dalam dunia travel agent diperlukan adanya pendidikan dan pengalaman karena jika tidak ada pendidikan dan pengalaman akan sangat sulit dalam melakukan perkerjaan ini, dan ini berlaku tidak hanya untuk pekerjaan sebagai travel agent saja melainkan untuk pekerjaan yang lain juga".

Namun ada satu orang yang memiliki pendapat yang berbeda yaitu bapak ocky dimana beliau berpendapat bahwa "seseorang tergantung pribadi dari orang yang bersangkutan, mau seseorang itu berpendidikan S2 sekalipun jika orang tersebut malas dan tidak punya keterampilan maka pekerjaan yang stabil tentunya akan sulit untuk di dapatkan, dan adapula seseorang yang hanya lulusan sd atau bahkan tidak sekolah jika seseorang 
tersebut punya keahlian dan gigih tetntunya tidak menutup kemungkinan orang tersebut akan dapat mempekerjakan seseorang yang lulusan S2".

Dalam hal ini penulis menyimpulkan dalam bisnis ini pendidikan dapat mempengaruhi pengetahuan dan pengalaman dari seorang travel agent untuk dapat menciptakan jalinan relasi yang baik dengan para traveler karena tidak menutup kemungkinan dengan adanya relasi yang baik para traveler yang merasa puas dengan pelayanan yang diberikan oleh travel agent akan kembali untuk menggunakan jasa para travel agent tersebut. Dan pendidikan dapat berpengaruh terhadap pekerjaan yang stabil tergantung daripada pengalaman dan juga usaha yang dilakukan oleh seseorang.

Pada dimensi ini meskipun penulis menitikberatkan pertanyaan pada budaya individualisme namun sikap yang ditunjukkan oleh para narasumber adalah termasuk dalam dimensi kolektivisme karena dasar dari moralitas narasumber ditandai dengan hubungan kerja yang menyerupai keluarga. karena pekerjaan ini dijalankan dengan sistem kekeluargaan atau dimensi kolektivisme dimana para karyawan saling berbagi ilmu dan pengetahuan sehingga sesama karyawan mendapatkan pengalaman dan pengetahuan secara tidak langsung dan hal ini membuat karyawan lain akan lebih tanggap dalam menjalankan pekerjaannya.

c. Dimensi Gender Association

Pertanyaan pada dimensi ini adalah sebagai berikut: apakah menyukai teman satu profesi itu penting?

Kebanyakan dari narasumber mengatakan bahwa "penting menyukai teman satu profesi karena dalam setiap pekerjaan yang kita lakukan selalunya tidak terlepas dari yang namanya berinteraksi dengan yang lainnya maka dari itu sudah semestinya kita bersikap professional dengan menyukai teman satu profesi sudah pasti akan saling menghargai, saling menerima, dan saling menghormati satu sama lain jika semua itu sudah tejalin maka ketika menghadapi masalahpun akan saling membantu".

Menurut bapak Ocky sebagai owner baginya "menyukai karyawan ditempat usahanya juga sangat penting karena mencari SDM baik itu tidaklah mudah makanya harus menjaga dan merawat mereka dengan penuh kasih sayang agar kinerjanya tetap baik dan terjaga".

Pentingkah bagi anda untuk selalu dapat perhatian dari pimpinan anda, ketika anda melakukan pekerjaan dengan baik?

Di sesi pertanyaan ini seorang narasumber yaitu Anri menjawab "jika perhatian dari pimpinan itu penting karena dengan diperhatikannya kinerja karyawan maka darisana akan timbul sebuah penghargaan sebagai best employee".

Sementara itu narasumber yang lain menjawab "perhatian dari pimpinan itu tidaklah penting karena yang terpenting adalah kepuasan konsumen lagi pula perhatian dari atasan itu tidak harus pada saat bekerja dengan baik saja namun ketika kita melakukan kesalahanpun kerapkali pimpinan juga akan memperhatikan kita".

Apabila anda sudah melakukan pekerjaan dengan baik, apakah penting bagi anda untuk memiliki peluang agar dapat dipromosikan (naik jabatan)?

"tentu saja penting, karena naik jabatan merupakan achievement dari proses pekerjaan seorang karyawan" itulah jawaban yang dikemukakan oleh sebagian narasumber, sementara indah dan anri berpendapat bahwa "dalam dunia pariwisata promosi tidak terlalu penting karna yang penting adalah bagaimana skill mempertahankan tamu yang datang. Selain daripada itu menurut indah pemimpin yang cerdas bisa menilai kinerja karyawannya jika pemimpin merasa kinerja karyawannya bagus maka pemimpin akan menempatkan ditempat yang baik".

Pertanyaan yang sedikit berbeda diajukan pada owner dan travel agent Malaysia yaitu apabila anda sudah maksimal dalam menjalankan bisnis ini, apakah penting bagi anda untuk memiliki peluang agar dapat membuka cabang di daerah lain atau negara lain?

Jawaban yang diutarakan adalah "sudah tentu jika ada kesempatan dan ada jalannya mengapa tidak untuk membuka usaha ini di luar daerah atau negara lain".

Ketika anda membayangkan memiliki pekerjaan yang sempurna, apakah penting bagi anda untuk dapat tetap tinggal di daerah yang anda sukai?

Beberapa narasumber mengatakan hal ini "tidak terlalu penting karena pekerja yang baik 
adalah pekerja yang selalu ontime sehingga selama pekerjaan tersebut disukai maka tidak masalah baginya untuk beradaptasi dan tinggal dimanapun sesuai lokasi tempat kerja itu" namun beberapa narasumber lainnya justru memiliki pendapat yang berbeda yaitu penting bagi mereka untuk tetap tinggal di lingkungan yang nyaman yang mereka sukai.

Dari hasil wawancara pada dimensi group attachment menunjukkan sisi femenity lebih mendominasi dibandingkan sisi masculinity. Dimana pada sisi masculinity lebih menekankan pada kemajuan perusahaan dengan tantangan dan pencapaian seorang karyawan yang tertuang dalam bentuk pengahargaan, sementara pada sisi feminity menunjukkan sisi kepedulian untuk melakukan kerjasama yang baik untuk sama-sama berkembang dalam meningkatkan kinerja karyawan dan juga dari perusahaan.

\section{d. Dimensi Uncertainty Avoidance}

Selanjutnya untuk pertanyaan dan jawaban pada dimensi ini adalah sebagai berikut:

Selama bekerja disini apakah anda sering sakit? Untuk pertanyaan ini narasumber kompak memberikan jawaban yang serupa yaitu "bahwa mereka tidak pernah sakit paling hanya merasa pegal ketika kegiatan terlalu padat". Untuk pertanyaan selanjutnya Di travel ini, Apakah dapat diterima Jika ada staff yang melanggar peraturan namun dia merasa bahwa pelanggaran tersebut adalah untuk kebaikan travel?

Jawaban yang di ungkapkan oleh narasumber adalah "yang namanya pelanggaran tetap harus ditindak lanjuti untuk memberikan efek jera pada pelanggar dan keputusan tertinggi dari sanksi pelanggaran ini ada pada pihak management".

Menurut anda, Apakah manager/ atasan yang baik itu perlu memiliki jawaban yang spesifik untuk setiap pertanyaan yang diajukan karyawannya?

Ada perbedaan pendapat dari salah satu narasumber yaitu bapak ocky yang mengatakan bahwa "seorang manager tidak perlu memiliki jawaban yang spesifik atas pertanyaan bawahannya karena yang terpenting adalah jujur dalam berbicara dan bertindak". Sementara narasumber yang lain menjawab "seorang pimpinan harus memiliki jawaban yang spesifik dalam menjawab setiap pertanyaan yang diajukan oleh staff nya karna jawaban atasan merupakan salah satu kunci kesuksesan dari bisnis ini"

Apakah anda sering merasa gugup atau tegang dalam menghadapi masalah yang terjadi ketika sedang bekerja?

Beberapa narasumber mengatakan "pada awalnya pasti sering merasa gugup dalam menghadapi masalah yang terjadi namun seiring berjalannya waktu dan bertambahnya pengalaman membawa grup dengan berbagai jenis permasalahan sudah tidak lagi merasa panik dalam menghadapi masalah yang terjadi".

Sementara untuk teh mela dan teh indah memiliki pendapat yang sedikit berbeda dengan narasumber yang lainnya.

Menurut teh mela beliau "sering merasa gugup ketika menghadapi suatu masalah dalam pekerjaan karna beliau termasuk orang yang berencana dengan baik jadi jika ada sesuatu yang tidak sesuai dengan rencana maka beliau akan merasa bahwa hal ini merupakan kegagalan yang harus diperbaiki oleh beliau". Sementara menurut teh indah "beliau akan merasa gugup tergantung dari masalahnya itu sendiri kalau masalahnya berat kadang suka bingung harus kayak gimana tapi kalau masalahnya standar ya santai saja".

Dari Dari jawaban narasumber diatas peneliti menyimpulkan bahwa dimensi ini termasuk pada dimensi budaya high uncertainty avoidance karena mereka sudah terbiasa dengan permasalahan yang terjadi sehingga kesalahankesalahan yang akan terjadi dapat diminimalisir dengan perencanaan yang matang sesuai dengan pengalaman yang terjadi pada mereka selama ini. Hal ini akan mempengaruhi sikap dari karyawan untuk berhati-hati dalam bertindak dan merencanakan segala sesuatunya dengan baik agar dapat menghindari masalah yang akan terjadi sehingga karyawan termotivasi untuk selalu memperbaiki kinerjanya dari waktu ke waktu untuk mencapai tujuan yang ingin dicapainya.

\section{e. Dimensi Time Orientation}

Pertanyaan pada dimensi ini adalah sebagai berikut: Seberapa pentingkah bagi anda untuk dapat membantu keluarga dan teman anda ketika mereka membutuhkan bantuan dari anda?

"Membantu orang itu penting tapi dengan melihat karakteristik seseorang tersebut dan sesuai dengan batas kemampuan yang 
kita miliki, karena narasumber percayaakan konsep rezeki kalau kita memudahkan orang maka allah akan mudahkan pula urusan kita".

Apakah penting bagi Anda untuk berhatihati dalam menggunakan uang supaya tidak menghabiskan lebih dari yang anda butuhkan?

"Sangatlah penting dalam mengontrol pengeluaran kita harus punya perencanaan keuangan yg baik agar tidak kesulitan di masa depan, salah satunya dengan berhemat dan menabung, karna jika uang tidak dipergunakan dengan baik maka pengeluaran akan tidak terkontrol apalagi penggunaan uang untuk hal-hal yang tidak perlu, cukup atau tidaknya batasan pengeluaran uang kita sendiri yang mengetahui apa yang kita butuhkan bukannya orang lain"

Seberapa bangga Anda menjadi warga negara di negara anda?

"Tidak ada satu orangpun yang tidak bangga dengan negara tempatnya dilahirkan. Dan kebanggaan tersebut akan sempurna ketika bisa maksimal kontribusi sebagai warga negara".

Menrurt anda, Apakah kerja keras adalah cara yang paling benar dan sesuai untuk mendapatkan hasil yang baik?

"Cara yang paling benar adalah kerja keras diimbangi dengan kerja cerdas maka akan mendapatkan hasil yang baik karna proses tidak akan menghianati hasil, jadi jika ingin mendapatkan hasil yang maksimal maka harus kerja dengan maksimal juga".

Gambaran pola pikir dari para narasumber menunjukkan bahwasanya narasumber berorientasi pada dimensi jangka panjang (long term orientation) karena mereka lebih mementingkan masa depan mereka dengan perencanaan yang terstruktur untuk lebih baik dalam menjalani pekerjaannya juga untuk kemajuan bisnis yang sedang dijalaninya mereka akan membuat perencanaan yang terstruktur dengan terus mengeksplorasi kreatifitas dari seorang karyawan demi kemajuan perusahaan dan diri sendiri

f. Dimensi Indulgence

Pada dimensi ini penulis mengajukan pertanyaan seperti: Seberapa besar dan pentingkah pemenuhan keinginan anda?
Dalam pertanyaan ini narasumber memiliki jawaban yang berbeda-beda pertama ada Nor Syafiqah yang mengatakan bahwasanya "untuk saat ini beliau sedang berfokus pada pemenuhan keluarga bukan pemenuhan keinginan pribadi" lalu ada Bapak ocky dan indah yang menjawab " $30 \%$ keinginan dan 70\% kebutuhan, kenapa seperti ini karena seringnya keinginan itu tidak terpenuhi demi memenuhi kebutuhan".

Sementara narasumber yang lain berpendapat bahwa "pemenuhan keinginan ini sangat penting sehingga narasumber akan berusaha untuk mewujudkan keinginan tersebut sebagai salah satu bentuk dari kepuasan pribadi".

Apakah penting bagi anda untuk melakukan "Me Time" ketika sedang libur kerja? "Me time merupakan meditasi terbaik untuk mengetahui dan menghargai diri sendiri, meski bekerja di travel kegiatannya adalah pergi mengantarkan orang untuk berlibur tapi tetap beda rasanya ketika berlibur sendiri, atau menghabiskan waktu bersama teman maupun bersama keluarga".

Apakah Anda bahagia dengan kehidupan anda saat ini? "Selalu bersyukur akan proses yang sedang dijalani dengan bahagia dan akan selalu bahagia karna jika tidak bahagia maka bagaimana akan membahagiakan keluarga setiap detiknya saya nikmati dan setiap detiknya saya memiliki plan untuk jauh lebih baik",

Seberapa sering keadaan atau orang lain mencegah anda untuk melakukan hal yang benar-benar ingin Anda lakukan? Bagi Mela, "hal ini tidak terlalu penting dan tidak terlalu mempengaruhi hidupnya karena apa yang mela lakukan biasanya akan di pikirkan matangmatang terlebih dahulu olehnya jadi orang lain itu hanya memberikan persetujuan dan sekedar mengingatkan saja".

Pada dimensi ini penulis menyimpulkan bahwa penulis tidak melihat adanya unsur restraint yang mengakibatkan narasumber menahan kesenangannya, justru malah sebaliknya meskipun ada sedikit penolakan dari orang sekitar terhadap sikap narasumber akan tetapi narasumber tetap melakukan apa yang menjadi kesenangannya sebagai refleksi dari hasrat dan perasaan narasumber.

Pada table 2 menunjukkan ringkasan dari Hubungan dimensi budaya kinerja organisasi dengan kerangka teori Hofstede 
Tabel 2:

Hubungan dimensi budaya kinerja organisasi dengan kerangka teori Hofstede

\section{Dimensi}

Power Distance

Group Attachment

Gender Association

Uncertainty Avoidance

Time Orientation

Indulgence
Pengaruh

Rendah

Kolektivisme

Feminity

Tinggi

Jangka Panjang

Positif
Penelitian ini menunjukkan hubungan dimensi budaya kinerja organisasi dengan kerangka teori Hofstede, dimana Budaya organisasi erat hubungannya dengan kepemimpinan, sebab setiap aspek kepemimpinan akan membentuk suatu budaya organisasi, setiap perusahaan memiliki sikap kepemimpinan yang berbeda-beda dengan gambaran fenomena budaya yang ada dalam setiap organisasi. Sehingga dapat dikatakan bahwa, melihat kepemimpinan suatu organisasi sama dengan melihat budaya yang ada dalam organisasi tersebut, gambaran dari perilaku karyawan yang ada pada agent travel ini menunjukkan perilaku dari individu karyawan telah sesuai dengan arahan dari atasan hal ini tercermin dari disiplin kerja, team work, sikap, integritas, dan lainnya. Budaya dalam organisasi yang baik ini tercipta oleh pemimpin yang dapat menangani karyawannya dengan baik.

Karena menerapkan sistim kerja yang bersifat kekeluargaan baik antara atasan dan bawahan, maupun antara individu karyawan itu sendiri maka mereka akan saling mengkomunikasikan segala sesuatunya, juga saling membantu dan mengingatkan antar anggota organisasi sehingga menjadikan semua anggota yang berada dalam organisasi ini menjadi lebih tanggap dalam mengahdapi masalah yang terjadi atau dengan kata lain adanya interaksi yang harmonis antar karyawan menjadikan karyawan lebih disiplin dan bertanggung jawab dalam melaksanakan tugasnya, selain daripada itu sistem kerja yang kekeluargaan ini menciptakan rasa nyaman dalam kerjasama tim hal ini menciptakan budaya organisasi yang membuat pelayanan kepada para traveler pun menjadi semakin baik dari waktu ke waktu.

Motivasi secara tidak langsung baik disadari maupun tidak terbentuk dari sikap dalam menghadapi situasi kerja di perusahaan, karyawan yang termotivasi oleh kebijakan yang ada di perusahaan akan secara sukarela untuk meningkatkan kinerjanya dengan terus menerus meningkatkan inovasi dan kreatifitas untuk mencapai suatu tujuan baik tujuan pribadi maupun tujuan perusahaan. Karena setiap orang memiliki potensi yang berbeda oleh karena itu perusahaan dituntut mampu memahami perilaku dari karyawannya tujuannya adalah agar karyawan memiliki kesempatan untuk mengaktualisasi kreasi kerjanya sehingga karyawan lebih bersemangat dalam melakukan pekerjaannya yang mana akan berdampak baik pada hasil yang sesuai dengan yang diharapkan oleh perusahaan.

Bekerja dalam bisnis travel agent, keramahan akan secara otomatis menjadi budaya organisasi hal ini dikarenakan mengharuskan karyawan untuk bertemu dengan orang dengan berbagai macam karakter orang setiap harinya sehingga karyawan dituntut untuk bersikap ramah kepada pelanggan, dimana keramahan ini akan menjadi salah satu penilaian dari para pelanggan dan menjadi salah satu daya tarik yang akan membuat pelanggan tertarik untuk kembali menggunakan jasa dari travel agent ini, jika banyak pelanggan yang tertarik untuk kembali menggunakan jasa travel ini hal ini juga akan memotivasi karyawan untuk selalu memperbaiki pelayanan kepada para pelanggan.

Seiring dengan pengalaman yang di rasakan oleh karyawan dan dengan komunikasi yang baik antar karyawan serta dengan kemampuan intelektual dan kemampuan fisik yang dimiliki oleh karyawan travel maka akan menjadikan kemampuan dari para karyawan tersebut semakin mumpuni dalam bidang ini, sehingga setiap permasalahan yang akan atau sedang terjadi ketika sedang melakukan perjalanan bersama para traveler akan secara otomatis dapat di minimalisir oleh karyawan sehingga tidak akan membuat pelanggan panik, dan tentunya hal ini pun akan menjadikan nilai tambah bagi baik bagi karyawan maupun bagi perusahaan.

\section{PENUTUP \\ Simpulan}

Penelitian ini menunjukkan hubungan antara dimensi budaya Hofstede dengan kinerja organisasi,

1. Power Distance: dalam hubungannya dengan dimensi ini dalam kerangka hofstede hubungan yang terjalin diantara atasan dan karyawan termasuk kedalam power distance 
rendah hal ini terlihat dari rendahnya jarak emosional yang tercipta antara atasan dan bawahan sehingga pada lini bisnis travel ini meminta saran dari karyawan dan saling mengutarakan pendapat itu sangat diperlukan karena hal ini akan akan mempengaruhi dalam pengambilan keputusan oleh manager selaku pimpinan dengan tujuan untuk mencapai tujuan bersama.

2. Group Attachment: moralitas dari narasumber pada dimensi ini ditandai dengan hubungan kerja yang menyerupai keluarga. Karena pekerjaan ini dijalankan dengan sistem kekeluargaan sehingga hubungannya dengan dimensi budaya hofstede termasuk dalam dimensi budaya kolektivisme. Yang mana motivasi yang terbangun dalam diri karyawan baik secara langsung maupun tidak langsung dipengaruhi oleh hubungan kolektivisme yang terjalin baik antara atasan dengan bawahan maupun antar individu dari karyawan itu sendiri. hal ini terjadi karena seringnya para karyawan maupun atasan saling mengutarakan pendapat maupun saling bertukar cerita mengenai pengalaman pribadi mereka.

3. Gender Association: pada dimensi ini group attachment menunjukkan sisi femenity lebih mendominasi daripada masculinity, yang menunjukkan sisi kepedulian untuk melakukan kerjasama yang baik untuk samasama berkembang dalam peningkatan kinerja karyawan dan juga dari perusahaan.

4. Uncertainty Avoidance: dalam bisnis ini dimensi ini termasuk pada dimensi budaya yang high uncertainty avoidance karena mereka sudah terbiasa dengan permasalahan yang berulang-ulang terjadi, sehingga membuat para karyawan lebih tanggap dalam menghadapi masalah yang sedang atau akan terjadi dalam situasi dan kondisi apapun dengan cara melakukan perencanaan yang matang agar dapat meminimalisir kesalahan-kesalahan yang akan merugikan perusahaan dikemudian hari.

5. Time Orientation: dimensi ini berorientasi pada dimensi jangka panjang (long term orientation) karena masing-masing dari individu ini lebih mementingkan masa depan mereka dengan perencanaan yang terstruktur untuk lebih baik dalam menjalani pekerjaannya sehingga seiring berjalannya waktu akan menambah kemampuan karyawan dalam melayani pengguna jasa travel mereka.

6. Indulgence: pada dimensi ini narasumber melakukan apa yang menjadi kesenangannya sebagai refleksi dari hasrat dan perasaan narasumber.Karena hasrat dan perasaan dari para karyawan yang tidak dikekang sehingga hal ini membuat karyawan lebih ekspresif dan total dalam melakukan pelayanan kepada para pengguna jasa travel mereka.

Setiap dimensi kerangka Hofstede digeneralisasi pada dampak kinerja organisasi, budaya organisasi adalah hasil dari kinerja organisasi dan kinerja karyawan. Organisasi juga dapat memperkuat budaya, sehingga budaya organisasi yang kuat akan selalu mendorong kinerja karyawan sehingga sangat penting untuk memahami perbedaan budaya antar karyawan yang saling berinteraksi, akhirnya penelitian ini memberikan pemahaman yang praktis tentang dampak lanjutan dari kinerja organisasi pada travel agent, kinerja organisasi secara keseluruhan cukup baik karena berbagai tantangan telah dihadapi oleh organisasi ini.

\section{Saran}

Untuk meningkatkan keefektifan dan efisiensi dalam kinerja organisasi keseimbangan gender antara masculinity dan feminity mungkin akan lebih berkontribusi pada kinerja organisasi yang lebih baik lagi. Untuk mendapatkan hasil yang maksimal dengan mempertimbangkan keterbatasan-keterbatasan yang ada dalam penelitian ini saran peneliti untuk penelitian selanjutnya adalah perlu menggunakan metode survei dengan kuesioner sebagai instrument penelitiannya dengan menambah responden dan lebih banyak mengembangkan pertanyaan yang diajukan.

\section{DAFTAR PUSTAKA}

Brotherton, B., and Adler, G. (1999). An integrative approach to enhancing customer value and corporate performance in the international hotel industry. Hosp. Manag. 18 (3), 261-272

Hofstede, G. (1991). Culture and Organisations: Software of the Mind, McGraw Hill, New York.

Hofstede, G. (2001). Culture's Consequences: Comparing Values, Behaviors, Institutions, and Organizations Across 
Nations (2nd ed.). California: Sage Publications, Inc.

Hofstede, G. G.J., Minkov, M. \& Vinken, H. (2008). Value Survey Module 2008 Manual. Retrieved16 January 2013 from http://www.geerthofstede.com/media/229 Imanualvsm08.doc.

Hofstede, G.J., Minkov, M. (2010). Cultures and Organizations: Software of the Mind. McGraw-Hill International (UK) Ltd, Maidenhead, UK.

Jones, D.L., McCleary, K.W., (2004). A model for assessing cultural impacts on international buyer-seller relationships for key accounts of hotel companies. $J$. Hosp. Tour. Res. 28 (4), 425-443.

Jones, P. (1999). Operational issues and trends in the hospitality industry. Int. J. Hosp. Manag. 18 (4), 427-442.

Mangkunegara, AP. (2008). Manajemen sumber daya manusia. Bandung: Remaja Rosda Karya. PT.

Moeheriono. (2010). Pengukuran kinerja berbasis kompetensi. Cetakan kedua. Jakarta: Ghalia Indonesia

Moleong, Lexy J. (2007). Metodologi penelitian kualitatif. Bandung: Remaja rosdakarya offset. PT

Nimran, Umar. (2005). Perilaku Organisasi. Surabaya: Citra Media. 